\title{
EVALUASI KINERJA OPERASIONAL PUSAT PELAYANAN KESEHATAN MASYARAKAT DI KOTA BOGOR
}

\author{
Herdiyana \\ Fakultas Ekonomi Universitas Pakuan
}

\begin{abstract}
Abstrak
Tujuan dari penelitian ini adalah untuk mengidentifikasi faktor-faktor lingkungan yang paling penting yang menyebabkan ragam pada kinerja Pusat Pelayanan Kesehatan Masyarakat (Puskesmas), mengukur efisiensi relatif Puskesmas umum di sektor publik menggunakan DEA, dan memeriksa intensitas dampak faktor-faktor lingkungan terhadap efisiensi relatif Puskesmas. Metode analisis data yang akan diterapkan adalah Data Envelopment Analysis (DEA), terdiri dari analisis kuantitatif dan analisis kualitatif. Hasil pengukuran efisiensi relatif Puskesmas umum di sektor publik menggunakan DEA model BCC (asumsi VRS) orientasi input dan output diperoleh dari enam Puskesmas di Kota Bogor, terdapat 4 Puskesmas yang masuk dalam kategori Puskesmas efisien (Achieved 100\%), diantaranya Puskesmas Bogor Timur, Puskesmas Kayu Manis, Puskesmas Bogor Selatan dan Puskesmas Tanah Sareal. Untuk Puskesmas yang tergolong dalam Puskesmas inefisien diantaranya adalah Puskesmas Warung Jambu (Achieved 91,16\%) dan Puskesmas Sempur (Achieved 93,75\%).
\end{abstract}

Kata kunci: Faktor Lingkungan, Puskesmas, Efisiensi Kinerja, Data Envelopment Analysis (DEA)

\section{PENDAHULUAN}

Pengukuran kinerja merupakan elemen yang menjadi fokus utama pada kinerja manajemen dianggap sebagai kegiatan inti di dalam fungsi manajemen (Fryer et al., 2009). Evaluasi kinerja membantu sistem sosial ekonomi untuk mengenali kekuatan dan kelemahan dan menyiapkan bisnis untuk memenuhi kebutuhan pelanggannya dengan lebih baik (Zhu, 2009).

Untuk mengukur kinerja, diperlukan pendekatan spesifik untuk menetapkan ukuran dan proksi kinerja yang jelas. Konsekuensinya, ukuran ini subyektif dan bukan merupakan alat yang "cocok untuk semua", bahkan untuk perusahaan sejenis dalam sebuah industri (PuigJunoy, 2000).

Sementara itu, perubahan fokus kinerja berdasarkan perspektif finansial beranjak ke perspektif non-finansial terutama pada sektor publik terus terjadi selama dekade terakhir. Perubahan-perubahan ini menyimpulkan hal penting, yaitu bahwa pendekatan ekonomi produksi yang mengasumsikan produktifitas organisasi (indeks non-finansial) sebagai kinerja pada tingkat perusahaan tampaknya layak digunakan (Langabeer, 2007; Ozcan, 2007; Taticchi et al., 2010).

Produktifitas dibagi menjadi dua bagian, yaitu efisiensi dan efektivitas (Kapyla et al, 2009). Meskipun dalam bebrapa penelitian (Karlaftis, 2004; Jacobs dan Smith, 2006; Balaguer-Coll et al., 2007) efisiensi diukur terpisah dari produktivitas, tetapi banyak studi mengevaluasi produktivitas hanya dengan mengukur efisiensi dan kedua definisi ini digunakan secara alternatif (Al-Shammari, 1999; Afonso dan Fernandex, 2008; Sadjadi dan Omrani, 2008; Ancarani et al., 2009).

Puskesmas umum merupakan organisasi jasa dimana ukuran-ukuran kemampulabaan dan keuangan dianggap kurang penting sebagai dasar evaluasi kinerja. Lingkungan eksternal Puskesmas seperti organisasi lainnya dibatasi dengan mengenali domainnya. Peubah-peubah lingkungan mempengaruhi kinerja organisasi (Daft, 2009). Faktor-faktor ini merupakan context-based dan demi pemahaman yang lebih baik mengenai keterkaitannya dengan kinerja untuk lembaga tertentu, faktor-faktor ini 
memerlukan penjelasan mendalam tentang dampaknya terhadap kinerja.

Dalam studi ini, faktor-faktor lingkungan eksternal yang mempengaruhi kinerja Puskesmas umum dieksplorasi dan dikuantifikasi. Ketepatan pemilihan faktorfaktor non-controllable diperiksa melalui regresi statistika terhadap indeks efisiensi Puskesmas yang diukur dengan analisis non- parametric yaitu metode data envelopment analysis (DEA). Setelahnya, faktor-faktor lingkungan yang memiliki dampak penting diimpor sebagai perubah non-controllable baru ke model DEA lainnya yang dibangun untuk mengetahui intensitas faktor-faktor yang berpengaruh pada efisiensi.

Pusat Pelayanan Kesehatan Masyarakat (Puskesmas) merupakan organisasi nirlaba multi input-multi output. Pendapatan dan kemampulabaan bukan merupakan indikator dan proksi penting untuk kinerja. Organisasi dalam sektor publik diharapkan untuk menghasilkan sejumlah output tertentu dengan menggunakan sumberdaya sekecil mungkin. Kemampuan ini dikuantifikasi sebagai ukuran efisiensi (ukuran kinerja dalam pendekatan ekonomi produksi).

DEA telah diverifikasi dan digunakan secara luas sebagai alat efektif yang dapat diandalkan untuk mengukur efisiensi relatif untuk lembagalembaga dengan proses produksi serupa di sektor publik. Studi ini memilih tehnik riset operasi DEA untuk menilai efisiensi relatif Puskesmas.

Penelitian dalam manajemen kinerja sistem kesehatan selalu menarik, karena outcome dari unit pelayanan ini berpengaruh langsung terhadap pembangunan sosial ekonomi berkelanjutan. Sebagai tambahan, Puskesmas umum menyerap sebagian besar anggaran kesehatan. Dengan demikian, mengetahui dan memodifikasi faktor-faktor eksternal yang memiliki dampak dominan terhadap efisiensi Puskesmas umum akan mendapat perhatian akademik maupun praktik.

Sejauh ini ada sejumlah besar literatur untuk pengukuran efisiensi rumah sakit (O'Neill et al., 2008) tetapi hanya ada beberapa penelitian namun penting dilakukan untuk mengeksplorasi dampak faktor eksogenus pada efisiensi Puskesmas.

Diantara faktor-faktor eksogenus yang sejauh ini terlihat mempengaruhi efisiensi Puskesmas adalah struktur kepemilikan (Tiemann dan Schreyoggm 2008), struktur pasar (Bates et al., 2006), sistem kesehatan regional (Aletras et al., 2007), efek merger (Groff et al, 2007), status Puskesmas sekolah kedokteran (Chen et al., 2005; Groskopf et al., 2005) dan penggunaan catatan medis elektronik (Kazley dan Ozcan, 2009).

Diantara studi-studi yang disebutkan, karya Bates et al. (2005) dapat dikaitkan dengan pemeriksaan dampak faktor lingkungan terhadap efisiensi rumah sakit. Namun demikian, studi ini hanya mencakup faktor tunggal lingkungan eksternal, sementara penelitian ini bertujuan mengidentifikasi faktorfaktor lingkungan non-controllable yang mempengaruhi kinerja Puskesmas umum di sektor publik, menetapkan proksi untuk faktorfaktor ini dan mengeksplorasi dampaknya pada skor efisiensi sebagai bahan pertimbangan para manager dalam modifikasi pemanfaatan sumberdaya untuk berproduksi pada ambang produksi efisien dan kemungkinan perubahan struktural untuk mengkompensasi dampak lingkungan pada kinerja organisasi.

Maksud penelitian ini adalah menyelidiki faktor-faktor lingkungan yang berdampak pada kinerja Puskesmas umum publik dan derajat pengaruh faktor-faktor ini terhadap kinerja (efisiensi). Untuk mencapai maksud ini, tujuan penelitian yang ditetapkan: Untuk mengidentifikasi faktor-faktor lingkungan yang paling penting yang menyebabkan ragam pada kinerja Puskesmas. Mengukur efisiensi relatif Puskesmas umum di sektor publik menggunakan DEA. Memeriksa intensitas dampak faktor-faktor lingkungan terhadap efisiensi relatif Puskesmas.

\section{KAJIAN LITERATUR \\ Data Envelopment Analysis}

Data Envelopment Analysis (DEA) adalah tehnik analisis non-parametrik, tidak membuat asumsi apapun tentang bentuk fungsi produksi atau teknologi. DEA merupakan pendekatan non-stokastik. Semua pengamatan diperlakukan 
sebagai non-stokastik. Nama dari teknik ini adalah karena kita mencoba membangun frontier perbatasan dengan membungkus (mengamplopi, memasukkan ke dalam amplop) semua vektor input-output yang diamati. Metode ini merupakan perluasan dari tehnik Free-Disposal-Hull; memaksakan kecembungan.

1. Pengukuran Efisiensi Puskesmas

\section{Menggunakan DEA}

Efisiensi relatif adalah rasio komparatif jumlah output terbobot terhadap jumlah input terbobot sebuah satuan pengambil keputusan (decision making units, DMU) dengan input serupa terhadap proses transformasi output dalam industri tertentu. Efisiensi tiap perusahaan diukur dengan menggunakan tehnik pemrograman linier. Untuk mengukur efisiensi relatif ada beberapa tehnik berbeda. Tehnik ini digolongkan menjadi metode parametrik dan non-parametrik.

Metode parametrik seperti metode ekonometrik atau Stochastic Frontier Analysis (SFA) atau fungsi biaya memerlukan asumsi tertentu tentang teknologi dan fungsi produksi, dimana metode non-parametrik seperti data envelopment analysis (DEA) atau free disposal hull (FDH) tidak menunjukkan karakteristik apapun untuk fungsi produksi dan hanya menggunakan informasi input-output untuk membangun production frontier dan menghitung inefisiensi relatif DMU dibawah frontier atau ambang tersebut (Jacobs, 2001; O'Neill et al., 2008).

DEA pertama kali diperkenalkan sebagai metodologi yang kuat oleh Charnes et al. (1978) berdasarkan hasil karya Farrell (1957) tentang efisiensi teknik.Semenjak itu DEA terus berkembang baik teori maupun aplikasinya (Cook dan Seiford, 2009).

Sejumlah besar model DEA dikembangkan dan diterapkan dalam berbagai konteks dan kondisi berbeda. Model-model Constant Returns to Scale (CRS), model-model Variable Returns to Scale (VRS), model-model runtut waktu, modelmodel pararel, deterministic, stochastic dan fuzzy, model-model network dan lainnya digunakan dan dimodifikasi terkait kasus yang menjadi kajian. Sherman (1984) merupakan orang pertama yang menggunakan DEA untuk mengukur efisiensi relatif Puskesmas.

DEA hanya menggunakan data input dan output Puskesmas untuk membangun production frontier untuk mengidentifikasi Puskesmas-Puskesmas yang inefisien dan sumberdaya Puskesmas-Puskesmas tersebut yang inefisien. O'Neill et al. (2008) mempersembahkan taksonomi komprehensif tentang studi-studi pengukuran efisiensi Puskesmas berbasis DEA.

\section{Dampak Faktor Lingkungan Terhadap Efisiensi}

Sejumlah besar studi berkenaan dengan dampak faktor-faktor lingkungan pada aspek organisasi yang berbeda muncul.Sebagian dari yang berhasil dari aspek-aspek ini adalah sistem perencanaan interorganisasional berbasis internet (Lee et al., 2005), inovasi jasa (Lee et al., 2009), manajemen dan strategi (Mason, 2007).

Namun demikian, juga ada penelitianpenelitian tentang dampak faktor-faktor lingkungan pada kinerja, tetapi kasusnya bukan Puskesmas. Misalnya, Giokas et al. (2009) memeriksa dampak lokasi pada efisiensi biaya beberapa cabang bank di Yunani; Bachiller (2009) menganalisis dampak kepemilikan pada lima perusahaan besar milik pemerintah di Spanyol dan Astami et al. (2010) menyelidiki dampak swastanisasi pada kinerja perusahaan pemerintah (badan usaha milik negara, BUMN) di Indonesia.

Prado-Lorenzo dan Garcia-Sanchez (2010) menilai dampak faktor-faktor yang tidak dikendalikan dari administrator publik pada efisiensi kotamadya terkait pelayanan limbah dan sampah. Faktor-faktor ini adalah ukuran operasional, faktor-faktor lingkungan dan tata kelola. Mereka mengambil responden penerima jasa, karakteristik demografik dan wilayah, permintaan dan iklim sebagai faktor lingkungan dan menetapkan proksi untuk masing-masing faktor untuk mempelajari dampaknya pada efisiensi. Faktor-faktor lingkungan dapat berdampak kepada kinerja Puskesmas. 


\section{METODOLOGI}

Studi ini melibatkan metode penelitian kualitatif maupun kuantitatif. Tahap awal berkaitan dengan pengukuran efisiensi Puskesmas-Puskesmas umum di kota Bogor. Untuk itu dibangun indeks untuk semua anggota populasi yaitu semua Puskesmas yang dipilih untuk analisis data, dengan demikian studi ini deskriptif dan deduktif pada tahap awal.

Mengingat biasanya biaya input dan harga output tidak nyata dalam organisasi sektor publik, DEA merupakan alat yang sesuai untuk mengukur efisiensi (rasio output berbobot terhadap input berbobot). Alasannya adalah bahwa DEA tidak memerlukan biaya dan harga untuk mengestimasi efisiensi. Apabila kasus yang diteliti (dalam hal ini Puskesmas) atau konteks (dalam hal ini sektor publik) berbeda, metode kuantitatif lainnya juga dapat diganti untuk pengukuran kinerja relatif. Dengan kata lain,
DEA hanyalah merupakan alat dalam riset ini dan tehnik kuantitatif lainnya dapat digunakan sebagai metoda alternatif untuk pengukuran kinerja.

\section{MODEL DEA CCR}

DEA membandingkan sejumlah unit berbasis sama pada input (sumberdaya) dan outputnya. Hasilnya menunjukkan apakah unit tertentu kurang produktif, atau efisien, dibandingkan dengan unit lainnya.

Untuk menggambarkannya, misalkan ada tujuh unit yang masing-masing memiliki satu input dan satu output: $\mathrm{L} 1=(2,2), \mathrm{L} 2=(3,5), \mathrm{L} 3=$ $(6,7), \mathrm{L} 4=(9,8), \mathrm{L} 5=(5,3), \mathrm{L} 6=(4,1), \mathrm{L} 7=(10,7)$.

Tiap input dan output dari unit-unit tersebut kemudian dipetakan pada pasangan koordinat $X$ atau garis horisontal untuk input dan koordinat $Y$ atau garis vertikal untuk output seperti tampak pada gambar berikut ini.

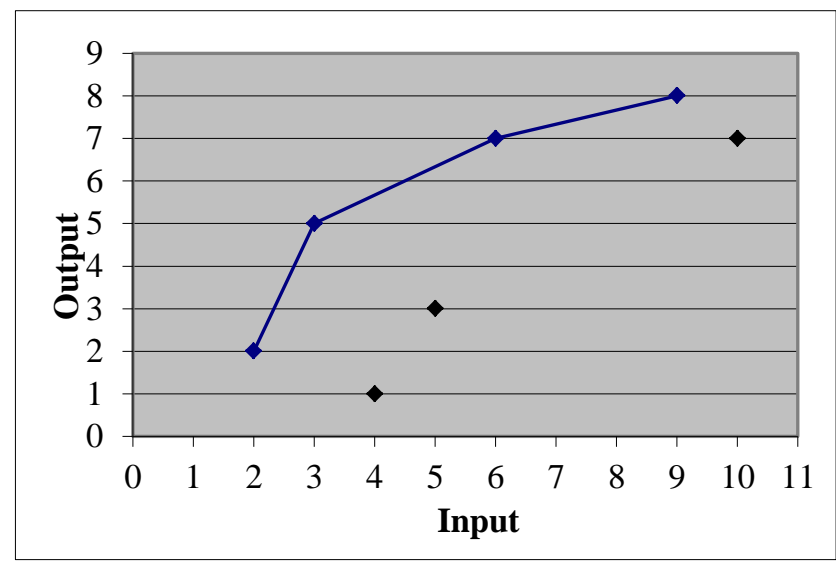

Gambar 1. Contoh peta efisiensi

Dengan demikian, ada dua definisi efisiensi tergantung pada tujuan evaluasi. Salah satunya mungkin terkait dengan pengurangan input yang dimungkinkan (dalam DEA ini disebut sebagai orientasi input) atau peningkatan output (orientasi output) dalam mencapai efisiensi teknis.

Tergantung pada tujuan evaluasi, analisis ini menyediakan set-set yang berbeda yang akan diperbandingkan. Bagaimanapun, kadangkala pengurangan input atau peningkatan output tidak efisien. Dalam contoh, bahkan bila L6 mengurangi inputnya dari 4 menjadi 2, masih ada kesenjangan diantaranya dan unit sesamanya L1 dalam jumlah satu unit output. Dalam DEA, kesenjangan ini disebut sebagai "slack" yang berarti excess input atau missing output yang terjadi bahkan setelah perubahan proporsional dalam input atau outputnya. Misalkan $(\mathrm{Yk}, \mathrm{Xk})=(\mathrm{Yki}, \mathrm{Xkj}), \mathrm{k}=1$ hingga $\mathrm{n}, \mathrm{i}=$ 1 hingga $s, j=1$ hingga $m$.

Maksimumkan $\mathrm{mYk} / \mathrm{nXk}$ untuk setiap nilai $k$ dari 1 hingga $n$, berkenaan dalam tiap kasus dengan $m Y j / n X j<=1, j=1$ hingga $n$, dimana:

mYk berarti Si mi* ${ }^{*} k i, i=1$ hingga $\mathrm{s}$, $n X k$ berarti Si ni*Xki, i = 1 hingga $m$ 
$m Y j$ berarti Si mi*Yji, $i=1$ hingga $s$ and $j=1$ hingga $n$

$n X j$ berarti Si ni*Xji, $i=1$ hingga $m$ and $j=1$ hingga $\mathrm{n}$.

mi, ni $>=0$

Sehingga:

$$
\begin{array}{cll}
\operatorname{Max}_{\Phi, \lambda} \Phi, & \\
\text { St } & { }_{\phi} \mathrm{q} \mathrm{i}+\mathrm{Q} \lambda & \geq 0, \\
& \mathrm{x}_{\mathrm{i}}-\mathrm{X} \lambda & \geq 0, \\
\mathrm{~N} 1^{\prime} \lambda & =1 \\
\lambda \quad \geq 0 &
\end{array}
$$

dimana $\phi$ adalah sebuah skalar: $1 \leq \phi<\infty$, dan $\mathrm{TE}=1 / \phi$.

Solusinya adalah set nilai maksimum untuk $m Y k / n X k$ dan nilai-nilai terkait untuk $\mathrm{m}$ dan $\mathrm{n}$.

\section{Analisis Data}

Seperti telah disampaikan sebelumnya, metode analisis data yang akan diterapkan adalah Data Envelopment Analysis (DEA) terdiri dari analisis kuantitatif dan analisis kualitatif. Kuantitatif dilakukan terhadap data sekunder Puskesmas umum di Kota Bogor. Untuk data kualitatif, dilakukan kuantifikasi melalui pembobotan skala Likert. Analisis yang akan diterapkan untuk data tersebut adalah analisis deskriptif komparatif, analisis kesenjangan dan analisis proses hirarki.

\section{Analisis Komparatif}

Tabel nilai permukaan yang diperoleh dari kuesioner yang disebar disetiap kecamatan (minimal diambil 15 responden setiap kecamatan) diperbandingkan satu sama lain dengan menggunakan peta efisiensi

\begin{tabular}{|c|c|c|c|}
\hline NO. & Nama Puskesmas & Alamat Puskesmas & Jenis Puskesmas \\
\hline 1 & Puskesmas Bogor Timur & Jl Pakuan No.6 kec. Bogor timur & Rawat Inap \\
\hline 2 & Puskesmas Warung Jambu & $\begin{array}{l}\text { Jl. Gatot Kaca BTN Indraprasta kec } \\
\text { bogor utara }\end{array}$ & Non-Rawat Inap \\
\hline 3 & Puskesmas Kayu Manis & $\begin{array}{l}\text { Jl. Pool Bina Marga No. } 3 \text { Kayumanis, } \\
\text { Kec. Tanah Sareal }\end{array}$ & Non-Rawat Inap \\
\hline 4 & Puskesmas Sempur & Jl. Sempur Kaler No. 100, Bogor Tengah & Non- Rawat Inap \\
\hline 5 & Puskesmas Bogor Selatan & $\begin{array}{l}\text { Jln Batu Tulis no } 42 \text { Balai Kambang } \\
\text { Bogor Selatan }\end{array}$ & Rawat Inap \\
\hline 6 & Puskesmas Tanah Sareal & Jalan Kesehatan No. 3 Tanah Sareal & Rawat Inap \\
\hline
\end{tabular}
operasional. Adapun yang menjadi sampe penelitian ini adalah enam Puskesmas dar enam kecamatan yang ada di Kota Bogor dengan rincian sebagai berikut:
Dari hasil olahan data kuesioner berdasarkan enam Puskesmas di atas dapat dijelaskan mengenai persepsi masyarakat terhadap jasa layanan kesehatan sebagai berikut:

1. Kunjungan masyarakat selama 3 bulan terakhir.

Tingkat kunjungan merupakan tanggung jawab Puskesmas dalam memberikan pelayanan perorangan (private goods) (KEMENKES, 2011). Pelayanan perorangan tersebut adalah rawat jalan dan untuk Puskesmas tertentu ditambah dengan rawat inap. Dijelaskan bahwa tingkat kunjungan masyarakat terhadap Puskesmas dalam 3 bulan terakhir cukup tinggi, disetiap Puskesmas lebih dari $50 \%$ responden menyatakan bahwa tingkat pelayanan kesehatan tingkat pertama ini masih menjadi minat utama untuk memeriksakan kesehatan masyarakat di Puskesmas terdekat. Puskesmas Warung Jambu memiliki tingkat kunjungan tertinggi dengan prosentase 
82\% dan berbeda tipis dengan Puskesmas Bogor Timur dengan prosentase kunjungan $80 \%$ dalam kunjungan tiga bulan terakhir, dilanjutkan dengan Puskesmas Sempur $57 \%$, Puskesmas Bogor Selatan 55\%, Puskesmas Kayu Manis 53\% dan Puskesmas Tanah Sareal sebesar 50\%.

2. Intensitas kunjungan yang dilakukan masyarakat terhadap layanan Puskesmas.

Intensitas kunjungan juga menunjukkan capaian indikator upaya pengobatan dan pemeriksaan laboratorium yang dilakukan Puskesmas berdasarkan Standar Pelayanan Minimal (SPM) (Kepmenkes No. 828/Menkes/SK/IX/2008). Dalam kurun waktu satu bulan tingkat intensitas kunjungan masyarakat sangat bervariatif antar masing-masing Puskesmas. Rata-rata dalam satu bulan kunjungan paling dominan di seluruh Puskesmas intensitas kunjungan antara 2-3 kali dalam sebulan.

3. Penilaian tingkat kepentingan Puskesmas bagi kepuasan masyarakat yang dinilai berdasarkan beberapa karakteristik.

i) Penanganan pasien

Layanan penanganan pasien dinilai sangat penting dari beberapa responden dari setiap Puskesmas yang ada di enam kecamatan di Kota Bogor. Pasien mengharapkan pelayanan yang selalu optimal dari setiap kunjungannya terhadap Puskesmas. Puskesmas Bogor Timur merupakan salah satu Puskesmas yang memberikan output tertinggi dari Puskesmas lainnya, dari sampel responden yang di ambil sebanyak $80 \%$ responden menyatakan bahwa tingkat penanganan pasien di
Puskesmas tersebut dinilai sangat penting.

ii) Kebersihan fasilitas

Lingkungan Puskesmas dalam hal kebersihan menjadi sebuah sajian layanan yang memberikan kenyamanan bagi pasien, oleh karena itu kebersihan fasilitas menjadi penilaian sangat penting bagi kepuasan pasien disetiap Puskesmas. Responden pada setiap Puskesmas sangat responsif akan tingkat kebersihan di lingkungan Puskesmas.

iii) Harga

Penetapan harga bagi layanan kesehatan yang dicanangkan oleh pemerintah melalui Puskesmas memberikan sebuah keterjangkauan bagi setiap masyarakat agar tetap bisa menikmati pengobatan dengan biaya yang terjangkau. $80 \%$ responden dari Puskesmas bogor timur menyatakan bahwa penetapan harga dari jasa layanan kesehatan tersebut dinilai sangat penting, begitu pula penilaian dari responden dari Puskesmas yang lain menyatakan demikian.

iv) Ragam pengobatan

Ketersediannya sarana dan prasana penunjang kesehatan dan dilengkapi oleh tenaga medis dan non-medis yang terampil yang dicanangkan oleh Puskesmas dapat lebih beragam jasa pengobatannya. Hal ini diharapkan oleh seluruh masyarakat agar memudahkan masyarakat untuk berobat tanpa ada rasa kawatir. Responden menganggap keberagaman pengobatan ini sangat penting sehingga mereka mendapat kepastian lebih bagi jasa layanan kesehatan yang ditawarkan oleh Puskesmas. 
4. Penilaian terhadap perasaan pasien tentang Puskesmas berdasarkan karakteristik berikut:

i. Penanganan pasien

Tingkat kepuasan terhadap penanganan pasien dari setiap responden di beberapa Puskesmas ada yang memberikan penilaian yang hampir sama antar Puskesmas. Pasien dari Puskesmas sempur dan Bogor selatan memberikan penilaian yang sama terhadap layanan yang diberikan oleh pihak Puskesmas, dari responden yang diambil sampel secara keseluruhan menyatakan penanganan pasien baik. Puskesmas Kayu Manis dan Tanah Sareal juga mendapatkan penilaian yang baik. Puskesmas Bogor Timur $60 \%$ responden menyatakan penangan pasien baik, $40 \%$ penanganan pasien buruk. Untuk Puskesmas Warung Jambu menjadi perhatian khusus dikarenakan $59 \%$ responden menyatakan bahwa penanganan pasien masih tergolong buruk. Diharapkan agar segera dilakukan perubahan atas kekurangankekurangan yang dilakukan dan pelayanan terhadap pasien hendaknya lebih ditingkatkan kembali, sehingga kedepannya pasien dapat merasakan kepuasan akan layanan kesehatan yang diberikan.

ii. Kebersihan Fasilitas

Berkaitan dengan
fasilitas dijelaskan
Puskesmas bahwa
penilaian yang paling baik, $87 \%$
responden menyatakan bahwa
Puskesmas Sempur dapat menjaga
kebersihan dari fasilitas layanan
kesehatan tersebut, diikuti oleh
Puskesmas Tanah Sareal dengan

penilaian $\quad 70 \% \quad$ responden menyatakan fasilitas bersih, dan Puskesmas Bogor Selatan dengan penilaian $65 \%$ dari responden juga menyatakan fasilitas bersih. Dari ketiga Puskesmas tersebut ada beberapa Puskesmas dengan penilaian menurut sebagian besar responden kebersihan fasilitas, Puskesmas tergolong tidak bersih, diantaranya Puskesmas Bogor Timur. $60 \%$ responden menyatakan fasilitas tidak bersih. Puskesmas Warung Jambu 59\% responden menyatakan tidak bersih, dan sama halnya Puskesmas Kayu manis 53\% responden juga menyatakan fasilitas kebersihan tergolong tidak bersih.

iii. Harga

Untuk harga yang ditetapkan, sebagian besar responden di semua Puskesmas menyatakan bahwa harga untuk berobat di Puskesmas masih tergolong murah dan pastinya terjangkau bagi seluruh kalangan lapisan masyarakat. Keterjangkauan ini memberikan hak yang sama bagi seluruh masyarakat untuk memperoleh akses yang mudah demi terwujudnya masyarakat yang sehat jasmani.

iv. Ragam pengobatan

Terdapat 4 Puskemas dengan penilaian jasa pelayanan pengobatan lebih beragam dan tergolong memiliki infrastruktur alat-alat kesehatan yang lebih lengkap. Diantaranya Puskesmas Warung Jambu dengan penilaian $82 \%$ pengobatan luas, Puskesmas Sempur 74\%, Puskesmas Tanah Sareal $73 \%$ dan Puskesmas Bogor Selatan $70 \%$ responden menyatakan ragam pengobatan luas. Adapun Puskesmas yang memiliki penilaian kelengkapan pengobatan tergolong 
sempit atau tidak lengkap yaitu Puskesmas Bogor Timur 80\% responden dan Puskesmas Kayu Manis 58\% responden menyatakan jasa pengobatan yang ditawarkan masih dalam katagori pengobatan sempit atau terbatas.

5. Beberapa penilaian yang menjelaskan tentang harapan terhadap pelayanan yang diberikan oleh Puskesmas kepada pasien:

i. Pelayanan yang ramah merupakan keharusan bagi Puskesmas

Layanan yang ramah baik dari tenaga medis maupun non-medis menjadi sebuah keharusan bagi setiap pasien yang datang untuk sekedar cek kesehatan atau juga untuk proses penyembuhan. Responden meberikan harapan bahwa kehadirannya dapat diterima dan dilayani dengan baik. Pasien memberikan nilai tambah bagi Puskesmas dengan pelayanan yang dapat memberikan kepuasan akan kebutuhan pasien.

ii. Ketepatan diagnosa merupakan keharusan bagi petugas medis Puskesmas

Begitu juga dengan ketepatan diagnosa dari tenaga medis dianggap sebuah keharusan dari pelayanan jasa kesehatan yang diberikan. Pasien akan lebih yakin akan pengobatan yang tergolong terjangkau memberikan dampak pengobatan yang efektif dan terpercaya.

iii. Ketelitian pemeriksaan pasien merupakan keharusan bagi petugas medis Puskesmas

Tingkat ketelitian pemeriksaan dinilai positif bagi seluruh responden, sebagian besar responden menyatakan sangat setuju akan pelayanan tersebut.
Pasien tidak perlu ragu lagi jika aspek salah satu layanan jasa kesehatan ini memang dapat dipenuhi oleh setiap Puskesmas.

iv. Keterampilan mengobati (kecepatan bertindak) merupakan keharusan bagi petugas medis Puskesmas

Keterampilan mengobati dan kecepatan bertindak dalam melayani pasien adalah sebuah keharusan yang harus diwujudkan oleh setiap petugas medis. Pasien setuju bahkan sangat setuju jika kesigapan dalam menangani pasien selalu dijunjung tinggi. Hal ini dapat dipercaya bahwa layanan yang diberikan dapat dijalankan dengan prima sehingga kepuasan pasien terhadap kemampuan layanan kesehatan yang diberikan dapat terjamin.

6. Tingkat kepentingan informasi mengenai keberadaan Puskesmas di mata masyarakat.

Dari beberapa media promosi yang ada, diperoleh hasil tingkat kepentingan yang dinilai oleh responden (pasien) dari enam Puskesmas di Kota Bogor, dari beberapa media tersebut pasien menyerap sejauh mana tingkat informasi yang ditawarkan tentang layanan jasa Puskesmas, berikut dipaparkan beberapa media informasi penawaran keberadaan Puskesmas sebagai sumber media informasi yang dinilai penting atau tidak penting bagi masyarakat, diantaranya adalah:

i. Televisi

Pemberian informasi mengenai keberadaan Puskesmas melalui televisi merupakan sumber yang penting bahkan sebagian besar responden disetiap Puskesmas mengatakan sangat penting 
informasi tersebut, responden berharap dari masing-masing Puskesmas dapat menilai perlunya menginformasikan akan keberadaan Puskesmas di tengah-tengah masyarakat yang memliki nilai penopang bagi terwujudnya masyarakat yang sehat jasmani. Informasi melalui televisi disamping merupakan sumber informasi yang sangat mudah diketahui oleh masyarakat dan juga televisi merupakan media yang selalu ditonton oleh masyarakat.

ii. Koran

Sumber informasi dari koran dinilai sumber penting, hal ini dijelaskan dari sebagian besar responden yang berkunjung dan menilai bahwa media koran bukan media utama sebagai sumber informasi yang dapat ditelaah dengan mudah oleh setiap masyarakat, namun responden menyatakan bahwa media ini tetap merupakan media penting dalam menginformasikan keberadaan Puskesmas dimasing-masing wilayah.

iii. Papan reklame

Papan reklame merupakan media yang dinilai sumber penting. Hal ini dijelaskan berdasarkan persepsi responden dari sebagian besar Puskesmas. Untuk Puskesmas Warung Jambu sebanyak $64 \%$ responden media informasi reklame dinilai sangat penting. Hal ini dapat dijadikan referensi untuk memperoleh informasi tentang keberadaan Puskesmas terdekat yang ada di tengah-tengah masyarakat.

iv. Surat

Surat merupakan sumber penting bagi masyarakat untuk mengetahui informasi mengenai keberadaan Puskesmas, namun beberapa responden menyatakan media informasi surat bukan media informasi yang penting, seperti halnya Puskesmas Bogor Timur sebanyak $60 \%$ responden menyatakan hal demikian. Hal ini perlu dikaji ulang untuk pemberian informasi berdasarkan media surat apakah sudah efektif atau belum atas informasi yang menjelaskan tentang keberadaan Puskesmas.

7. Penilaian persepsi pasien dari masingmasing Puskesmas berdasarkan beberapa karakteristik berikut:

i. Pelayanan yang ramah merupakan keharusan bagi Puskesmas

Puskesmas dinilai dari pelayanan yang ramah diperoleh dari umpan balik oleh responden sekaligus pasien pada masingmasing Puskesmas. Umpan balik dikategorikan dalam dua jenis pelayanan, yaitu dalam kategori pelayanan baik dan kategori pelayanan buruk. Lima dari enam Puskesmas memperoleh umpan balik yang memiliki tingkat pelayanan baik menurut responden. Puskemas sempur $100 \%$ responden menyatakan pelayanan baik, diikuti Puskesmas Bogor Selatan, Puskesmas Bogor Timur, Puskesmas Kayu Manis dan Puskesmas Tanah Sareal. Puskesmas Warung Jambu memiliki penilaian yang buruk akan keramahan pelayanan yang diberikan, dinyatakan oleh 59\% responden bahwa pelayanan masih tergolong buruk. Hal ini diharapkan menjadi masukan bagi Puskesmas untuk memperbaiki pelayanan yang lebih ramah terhadap penanganan pasien yang datang untuk berobat karena kepuasan pelayanan 
terhadap pasien menjadi nilai tambah bagi Puskesmas.

ii. Ketepatan diagnosa merupakan keharusan bagi petugas medis Puskesmas

Sebuah keharusan bagi petugas medis didalam melaksanakan tugas yang sesuai dengan ketepatan memberikan diagnosa bagi pasien Puskesmas tersebut. Sebagian besar responden memberikan penilaian yang baik bagi pelayanan yang telah diberikan. Puskesmas Sempur $83 \%$, Puskesmas Bogor Selatan 75\%, Puskesmas Kayu Manis 74\%, dan Puskesmas Tanah Sareal $70 \%$ responden menyatakan baik. Hanya Puskesmas Warung Jambu yang memberikan penilaian buruk akan ketepatan diagnosa yang dilakukan. 59\% responden menjelaskan bahwa hal tersebut masih dalam pelayanan yang belum maksimal.

iii. Ketelitian pemeriksaan pasien merupakan keharusan bagi petugas medis Puskesmas

Tingkat ketelitian pemeriksaan terhadap pasien juga menjadi sebuah hal yang penting bagi pemberian kepercayaan dari seorang pasien terhadap petugas medis yang menangani. Respon positif atas pelayanan ini dituntut supaya pihak Puskesmas selalu memberikan jasa pelayanan kesehatan yang benar-benar dapat diterima masyarakat secara luas. Puskesmas Sempur responden masih mempercayakan pelayanan ini dengan baik, sebanyak $83 \%$ responden menyatakan baik. Puskesmas Bogor Selatan 80\% responden menyatakan baik. Puskesmas Kayu Manis $80 \%$ responden menyatakan baik dan Puskesmas Tanah Sareal 67\% menyatakan baik, begitu pula dengan Puskesmas Bogor Timur $60 \%$ responden menyatakan baik. Lain halnya dengan Puskesmas Warung Jambu yang memliki penilaian buruk akan ketelitian penaganan pasien. Dari responden yang ada $59 \%$ menyatakan pelayanan masih buruk.

iv. Ketrampilan mengobati (kecepatan bertindak) merupakan keharusan bagi petugas medis Puskesmas

Dari ke enam Puskesmas, masing-masing responden disetiap Puskesmas memberikan penilaian yang baik terhadap ke enam Puskesmas tersebut. Petugas medis di setiap Puskesmas dinilai terampil dan cepat bertindak dalam pengobatan yang dilakukan. Puskesmas Kayu manis dari responden yang ada, $100 \%$ responden menyatakan pelayanan Puskesmas dalam keterampilan mengobati dan kecepatan bertindak dinilai baik. Hal yang sama juga dinyatakan terhadap Puskesmas lainnya.

v. Pemberian rujukan yang cepat dan tepat merupakan keharusan bagi manajemen Puskesmas

Puskesmas Sempur mendapatkan penilain yang tertinggi dari hasil penilaian oleh responden, $83 \%$ responden menyatakan bahwa pemberian rujukan dilakukan dengan cepat dan tepat oleh manajeman Puskesmas, diikuti oleh Puskesmas Bogor Selatan $80 \%$, Puskesmas Kayu Manis 74\%, Puskesmas Tanah Sareal 73\%, Puskesmas Bogor Timur 60\% dan Puskesmas Warung Jambu 59\%. Namun terdapat juga responden yang memberikan penilaian buruk terhadap pelayanan Puskesmas ini. Hal ini berarti perlu perbaikan 
kembali atas ketidakoptimalan pelayanan untuk kedepannya supaya respon baik dari pasien menjadi sebuah pengoptimalan kerja terhadap jasa pelayanan kesehatan bagi masyarakat.

8. Tingkat kunjungan terhadap layanan medis yang dilakukan dalam 3 bulan terakhir oleh pasien.

\section{i. Puskesmas}

Intensitas kunjungan pasien terhadap Puskesmas paling dominan rata-rata dilakukan sebanyak satu kali sebulan atau kurang, bahkan dibeberapa Puskesmas responden mengunjungi Puskesmas untuk berobat hampir rutin setiap kali dalam seminggu. Contohnya responden Puskesmas Tanah Sareal, 43\% responden menyatakan melakukan kunjungan satu kali dalam seminggu. Bahkan $41 \%$ respoden di Puskesmas Warung Jambu menyatakan tingkat kunjungan terhadap puskesmas dilakukan dua atau tiga kali dalam seminggu. Hal ini menandakan antusias masyarakat cukup tinggi untuk memeriksakan kesehatan di Puskesmas.

ii. Dokter praktek

Sebagian besar responden dari keseluruhan Puskesmas melakukan kunjungan ke dokter praktek ratarata satu kali sebulan atau kurang. Dari situasi tersebut dapat disimpulkan bahwa intensitas kunjungan terhadap dokter praktek tidak terlalu tinggi. Hanya sebagian kecil responden saja yang melakukan kunjungan dari satu kali seminggu hingga dua atau tiga kali dalam seminggu.

iii. Rumah sakit

Tingkat kunjungan terhadap rumah sakit juga tergolong dengan intensitas kunjungan yang rendah. Sebagian besar responden disetiap Puskesmas menyatakan kunjungan dilakukan maksimal satu kali dalam sebulan bahkan bisa tidak sama sekali. Puskesmas Sempur dari $100 \%$ responden menyatakan kunjungan dilakukan satu kali sebulan bahkan kurang.

iv. Lainnya

Untuk jenis tempat layanan medis lainnya tingkat kunjungan juga tidak terlalu tinggi. Sebagian besar responden menyatakan kunjungannya hanya dilakukan satu kali sebulan bahkan kurang atau tidak sama sekali. Dapat disimpulkan dari beberapa tempat layanan medis yang ada, pasien atau khususnya responden lebih tertarik melakukan pengobatan di Puskesmas, dapat dilihat dari tingkat intensitas kunjungan yang lebih tinggi. Kunjungan dapat dilakukan mulai dari satu kali seminggu bahkan ada yang hingga dua atau tiga kali dalam seminggu. Hal ini menandakan ketertarikan yang tinggi dari setiap elemen masyarakat untuk memperoleh kemudahan dalam pengobatan dan keterjangkauan dari segi harga yang ditawarkan.

\section{Perhitungan Efisiensi Relatif Puskesmas}

Dari 6 Puskesmas di Kabupaten Bogor yang diteliti, terdapat 4 Puskesmas yang efisien secara teknis dan 2 Puskesmas tidak efisien secara teknis. Puskesmas yang efisien secara teknis adalah Puskesmas dengan nilai efisiensi $100 \%$, yaitu Puskesmas Bogor Timur, Puskesmas Kayu Manis, Puskesmas Bogor Selatan dan Puskesmas Tanah Sareal. Kemudian untuk Puskesmas yang tidak efisiensi adalah Puskesmas dengan nilai efisiensi di bawah $100 \%$ yaitu Puskesmas Warung Jambu 
dan Puskesmas Sempur. Nilai efisiensi dari Puskesmas-Puskesmas yang tidak efisien juga berbeda-beda. Jika dilakukan pemeringkatan, maka Puskesmas yang mempunyai nilai efisiensi terendah adalah Puskesmas Warung Jambu, dengan nilai $81,16 \%$. Peringkat 1 adalah Puskesmas yang efisien $100 \%$ sedangkan peringkat 2 dan seterusnya adalah Puskesmas yang tidak efisien (<100\%), diurutkan berdasarkan nilai efisiensi, dari yang terbesar ke terkecil. Dengan demikian, hipotesis penelitian sudah terbukti bahwa sebagian besar Puskesmas di Kota Bogor sudah efisien secara teknis

(67\%).

Tabel 3.2. Nilai Efisiensi Teknik 6 Puskesmas Di Kabupaten Bogor Model DEA VRS orientasi Input

\begin{tabular}{|l|c|c|}
\hline Puskesmas & Efisiensi & Peringkat \\
\hline Bogor Timur & $100 \%$ & 1 \\
\hline Warung Jambu & $81,16 \%$ & 3 \\
\hline Kayu Manis & $100 \%$ & 1 \\
\hline Sempur & $83,75 \%$ & 2 \\
\hline Bogor Selatan & $100 \%$ & 1 \\
\hline Tanah Sareal & $100 \%$ & 1 \\
\hline
\end{tabular}

(Sumber: hasil olahan SPSS)

Analisis lain dapat dilakukan dengan membandingkan nilai efisiensi suatu Puskesmas dengan nilai efisiensi rata-rata. Analisis ini dapat membantu untuk memberikan gambaran seberapa banyak Puskesmas yang mempunyai efisiensi lebih rendah dibandingkan dengan Puskesmas lain secara rata-rata. Nilai efisiensi rata-rata adalah ( $88,25 \%)$. Jika dilakukan analisis berdasarkan rata-rata nilai efisiensi 6 Puskesmas di Kota Bogor, terdapat 2 Puskesmas yang mempunyai nilai efisiensi di bawah nilai efisiensi rata-rata (33\%) dari jumlah Puskesmas, yang semuanya adalah Puskesmas yang tidak efisien secara teknis. Secara rata-rata, output yang dihasilkan oleh Puskesmas yang tidak efisien adalah lebih rendah dibandingkan output Puskesmas yang efisien.

Tabel 3.3 Statistik Deskriptif Puskesmas Efisien

\begin{tabular}{|l|c|c|c|c|c|}
\hline \multicolumn{1}{|c|}{ Variabel } & N & Minimum & Maximum & Mean & Std. Deviation \\
\hline Infrastruktur Fisik & 4 & 0,227273 & 0,909091 & 0,563636 & 0,184431 \\
\hline Indeks Peralatan & 4 & 0,352941 & 1 & 0,839853 & 0,172682 \\
\hline Jumlah tempat tidur & 4 & 10 & 20 & 15 & 4 \\
\hline Pengeluaran obat (Rp) & 4 & 25.238 .900 & 606.000 .000 & 205.200 .000 & 139.454 .000 \\
\hline Pengeluaran pemeliharaan (Rp) & 4 & 78.616 .003 & 313.000 .000 & 167.280 .000 & 499.572 .000 \\
\hline Infrastruktur Khusus & 4 & 1 & 12 & 4,9 & 3,127131 \\
\hline Peralatan Khusus & 4 & 3 & 83 & 30,05 & 26,03939 \\
\hline Jam OPD per minggu & 4 & 28 & 44 & 35,65 & 3,59 \\
\hline Jam laboraturium per minggu & 4 & 28 & 168 & 91,70 & 64,48 \\
\hline Dokter & 4 & 1 & 8 & 3,4839 & 1,52471 \\
\hline Perawat & 4 & 2 & 11 & 5,61291 & 2,077296 \\
\hline Paramedis & 4 & 3 & 15 & 7,48388 & 2,769728 \\
\hline Administratif & 4 & 2 & 8 & 3,74194 & 1,384864 \\
\hline Non-Tehnis & 4 & 1 & 4 & 1,87097 & 0,692432 \\
\hline
\end{tabular}

JIMFE (Jurnal Ilmiah Manajemen Fakultas Ekonomi)

Volume 2 No. 2 Tahun 2016, Hal. 26-50 


\begin{tabular}{|l|c|c|c|c|c|} 
Kasus Legal Medis & 4 & 0 & 0 & 0 & 0 \\
\hline Kasus Laboratorium & 4 & 573 & 4.584 & $2.578,5$ & 916,8 \\
\hline Pasien rawat inap & 4 & 784 & 6.272 & $3.528,00$ & $1.254,400$ \\
\hline Pasien rawat jalan & 4 & 1.298 & 119.621 & $43.192,05$ & $30.114,02$ \\
\hline Kasus kesehatan ibu dan anak & 4 & 7.336 & 13.070 & 10.203 & 2.614 \\
\hline
\end{tabular}

(Sumber: hasil olahan SPSS)

Sedangkan rata-rata penggunaan input dan output pada Puskesmas inefisien dapat dilihat pada tabel di bawah ini.

Tabel 3.4 Statistik Deskriptif Puskesmas Inefisien

\begin{tabular}{|l|c|c|c|c|c|}
\hline \multicolumn{1}{|c|}{ Variabel } & N & Minimum & Maximum & Mean & Std. Deviation \\
\hline Infrastruktur Fisik & 2 & 0,64 & 0,95 & 0,78 & 0.09 \\
\hline Indeks Peralatan & 2 & 0,21 & 1 & 0,82 & 0,19 \\
\hline Jumlah tempat tidur & 2 & 15 & 25 & 20 & 5 \\
\hline Pengeluaran obat (Rp) & 2 & 193.000 .000 & 416.000 .000 & 277.860 .000 & 77.766 .400 \\
\hline Pengeluaran pemeliharaan (Rp) & 2 & 147.000 .000 & 238.000 .000 & 192.480 .000 & 32.705 .600 \\
\hline Infrastruktur Khusus & 2 & 1 & 12 & 4,9 & 3,127131 \\
\hline Peralatan Khusus & 2 & 3 & 100 & 42,19512 & 27,77159 \\
\hline Jam OPD per minggu & 2 & 28 & 44 & 35,65 & 3,59 \\
\hline Jam laboraturium per minggu & 2 & 30 & 36 & 41,25 & 9,26 \\
\hline Dokter & 2 & 2 & 6 & 3,7778 & 1,30171 \\
\hline Perawat & 2 & 3,6 & 8,1 & 5,96667 & 1,758552 \\
\hline Paramedis & 2 & 4,8 & 10,8 & 7,95556 & 2,344736 \\
\hline Administratif & 2 & 2,4 & 5,4 & 3,97778 & 1,172368 \\
\hline Non Tehnis & 2 & 1,2 & 2,7 & 1,98889 & 0,586184 \\
\hline Kasus Legal Medis & 2 & - & - & - & - \\
\hline Kasus Laboratorium & 2 & 536 & 4.288 & 2.412 & 858 \\
\hline Pasien rawat inap & 2 & 662 & 5.296 & 2.979 & 1.059 \\
\hline Pasien rawat jalan & 2 & 1.038 & 95.697 & 34.554 & 24.091 \\
\hline Kasus kesehatan ibu dan anak & 2 & 5.869 & 10.456 & 8.162 & 2.091 \\
\hline (Sumber: hasil
\end{tabular}

(Sumber: hasil olahan SPSS)

Berdasarkan tabel di atas dapat dilihat bahwa rata-rata penggunaan input pada Puskesmas efisien dengan Puskesmas tidak efisien. Puskesmas efisien lebih sedikit menggunakan input, misalnya jumlah pembiayaan untuk pengeluaran obat adalah sebesar Rp205.200.000 sedangkan pada Puskesmas tidak efisien lebih banyak yaitu berjumlah Rp277.860.000. Rata-rata pengeluaran pemeliharaan Rp167.280.000 pada Puskesmas efisien. Berbeda dengan Puskesmas inefisien, pengeluaran lebih besar dengan biaya pemeliharaan sebesar Rp192.480.000. Untuk rata-rata penunjang tempat tidur pada Puskesmas efisien sebanyak 15 tempat tidur, dan sedangkan untuk Puskesmas inefisien sebanyak 20 tempat tidur. Sama halnya dengan ketersediaan tenaga perawat pada Puskesmas efisien rata-rata sebanyak 15 tenaga perawat, sedangkan untuk Puskesmas inefisien jumlah tenaga perawat rata-rata sebanyak 20 orang. 
Jika ketersediaan input lebih besar pada puskesmas inefisien, sebaliknya dengan jumlah output yang dihasilkan oleh Puskesmas inefisien lebih kecil dari pada Puskesmas yang memiliki tingkat efisiensi optimal. Dapat dilihat pada tabel di atas ratarata kasus laboratorium yang dapat tertangani sebesar $2.578,5$, sedangkan untuk
Puskesmas inefisien rata-rata penanganan kasus laboratorium yang dapat tertangani sebesar 2.412. Untuk penanganan pasien rawat jalan pada Puskesmas efisien dapat menangani pasien dengan rata-rata penanganan sebanyak 43.192,05. Untuk Puskesmas inefisien hanya dapat melakukan penanganan sebanyak 34.554.

\section{Efesiensi Skala}

Tabel 3.5 Nilai Efisiensi Skala 6 Puskesmas di Kota Bogor

\begin{tabular}{|l|c|c|c|}
\hline Puskesmas & CRS Output (\%) & VRS Output (\%) & Efisiensi Skala \\
\hline Bogor Timur & $100 \%$ & $100 \%$ & $100 \%$ \\
\hline Warung Jambu & $73,82 \%$ & $81,16 \%$ & $76,98 \%$ \\
\hline Kayu Manis & $100 \%$ & $100 \%$ & $100 \%$ \\
\hline Sempur & $74,49 \%$ & $83,75 \%$ & $84,86 \%$ \\
\hline Bogor Selatan & $100 \%$ & $100 \%$ & $100 \%$ \\
\hline Tanah Sareal & $100 \%$ & $100 \%$ & $100 \%$ \\
\hline
\end{tabular}

(Sumber: Hasil olahan DEA)

Beradasarkan Tabel di atas terdapat 4 Puskesmas dengan memliki skala efisiensi $100 \%$, dan terdapat 2 Puskesmas yang berada pada penilaian belum optimal, yang ditunjukkan oleh tingkat efisiensi skala bernilai kurang dari $100 \%$. Seluruh Puskesmas yang tidak efisien secara teknis juga berdampak tidak efisiensi secara skala. Sedangkan 4 Puskesmas yang efisien secara teknis dapat dilihat pada kolom VRS output terdapat Puskesmas dengan skala tidak efisien yaitu
Puskesmas Warung Jambu dan Puskesmas Sempur. Untuk kedua Puskesmas ini terjadi kondisi ketika Puskesmas tidak dapat beroperasi pada skala optimum.

\section{Puskesmas Inefisien dan Penyebabnya.}

Puskesmas dengan penilaian tidak efisien dijelaskan dalam tabel di bawah ini, dari masing-masing inefisiennya yang dicapai diberikan nilai solusi perbaikan berdasarkan perhitungan dari analisis DEA.

Tabel 3.6. Puskesmas Inefisien dan penyebabnya

\begin{tabular}{|c|c|c|c|c|c|c|c|}
\hline \multirow[b]{2}{*}{ No } & \multirow[b]{2}{*}{ Puskesmas } & \multirow[b]{2}{*}{ Score } & \multirow[b]{2}{*}{ Variabel } & \multicolumn{4}{|c|}{ Perbaikan Mengacu Benchmarks } \\
\hline & & & & Actual & Target & $\begin{array}{l}\text { To Gain } \\
\text { (\%) }\end{array}$ & $\begin{array}{l}\text { Achived } \\
\text { (\%) }\end{array}$ \\
\hline \multirow[t]{7}{*}{1} & Warung Jambu & $91,16 \%$ & Infrastruktur Fisik & 0,643434 & 0,643434 & $0 \%$ & $100,0 \%$ \\
\hline & & & Indeks Peralatan & 0,963263 & 0,934768 & $3 \%$ & $97,0 \%$ \\
\hline & & & Jumlah tempat tidur & 12 & 10 & $17 \%$ & $83,3 \%$ \\
\hline & & & Pengeluaran obat (Rp) & 352.589 .632 & 248.778 .225 & $29 \%$ & $70,6 \%$ \\
\hline & & & $\begin{array}{l}\text { Pengeluaran } \\
\text { pemeliharaan (Rp) }\end{array}$ & 197.502 .716 & 179.172 .214 & $9 \%$ & $90,7 \%$ \\
\hline & & & Infrastruktur Khusus & 6,3 & 5,9 & $6 \%$ & $93,7 \%$ \\
\hline & & & Peralatan Khusus & 34,02 & 32,05 & $6 \%$ & $94,2 \%$ \\
\hline
\end{tabular}

JIMFE (Jurnal Ilmiah Manajemen Fakultas Ekonomi)

Volume 2 No. 2 Tahun 2016, Hal. 26-50 


\begin{tabular}{|c|c|c|c|c|c|c|c|}
\hline & & & $\begin{array}{l}\text { Jam OPD per minggu } \\
\text { Jam laboratorium per } \\
\text { minggu } \\
\text { Dokter } \\
\text { Perawat } \\
\text { Paramedis } \\
\text { Administratif } \\
\text { Non-Tehnis } \\
\text { Kasus Legal Medis } \\
\text { Kasus Laboratorium } \\
\text { Pasien rawat inap } \\
\text { Pasien rawat jalan } \\
\text { Kasus kesehatan ibu dan } \\
\text { anak }\end{array}$ & $\begin{array}{r}38,45 \\
94,7 \\
3 \\
7 \\
8 \\
4 \\
3 \\
0 \\
2.196,0 \\
0 \\
33.112,00 \\
7.423\end{array}$ & $\begin{array}{r}36,65 \\
92,40 \\
3 \\
6,25462 \\
7,83246 \\
3,74194 \\
1,87097 \\
0 \\
2.446,0 \\
0 \\
34.445,00 \\
8.191\end{array}$ & $\begin{array}{r}2 \% \\
0 \% \\
11 \% \\
2 \% \\
6 \% \\
38 \% \\
0 \% \\
10 \% \\
0 \% \\
4 \% \\
9 \%\end{array}$ & $\begin{array}{r}95,3 \% \\
97,6 \% \\
100,0 \% \\
89,4 \% \\
97,9 \% \\
93,5 \% \\
62,4 \% \\
0,0 \% \\
89,8 \% \\
0,0 \% \\
96,1 \% \\
90,6 \%\end{array}$ \\
\hline 2 & Sempur & $93,75 \%$ & $\begin{array}{l}\text { Infrastruktur Fisik } \\
\text { Indeks Peralatan } \\
\text { Jumlah tempat tidur } \\
\text { Pengeluaran obat (Rp) } \\
\text { Pengeluaran } \\
\text { pemeliharaan (Rp) } \\
\text { Infrastruktur Khusus } \\
\text { Peralatan Khusus } \\
\text { Jam OPD per minggu } \\
\text { Jam laboratorium per } \\
\text { minggu } \\
\text { Dokter } \\
\text { Perawat } \\
\text { Paramedis } \\
\text { Administratif } \\
\text { Non-Tehnis } \\
\text { Kasus Legal Medis } \\
\text { Kasus Laboratorium } \\
\text { Pasien rawat inap } \\
\text { Pasien rawat jalan } \\
\text { Kasus kesehatan ibu dan } \\
\text { anak }\end{array}$ & $\begin{array}{r}0,852212 \\
0,986421 \\
10 \\
279.681 .782 \\
\\
215.078 .910 \\
18 \\
35,01 \\
38,55 \\
94,56 \\
2 \\
7 \\
8 \\
4 \\
2 \\
0 \\
2.289,0 \\
0 \\
33.126,00 \\
7.856\end{array}$ & $\begin{array}{r}0,852212 \\
0,924723 \\
10 \\
279.681 .782 \\
\\
197.468 .515 \\
16,4 \\
31,08 \\
36,8 \\
92,72 \\
2 \\
5,63521 \\
8 \\
4 \\
1,26594 \\
0 \\
2.378,0 \\
0 \\
34.663,00 \\
8.133\end{array}$ & $\begin{array}{r}0 \% \\
6 \% \\
0 \% \\
0 \% \\
\\
8 \% \\
9 \% \\
11 \% \\
5 \% \\
\\
2 \% \\
0 \% \\
19 \% \\
0 \% \\
0 \% \\
37 \% \\
0 \% \\
4 \% \\
0 \% \\
4 \% \\
\\
3 \%\end{array}$ & $\begin{array}{r}100,0 \% \\
93,7 \% \\
100,0 \% \\
100,0 \% \\
\\
91,8 \% \\
91,1 \% \\
88,8 \% \\
95,5 \% \\
\\
98,1 \% \\
100,0 \% \\
80,5 \% \\
100,0 \% \\
100,0 \% \\
63,3 \% \\
0,0 \% \\
96,3 \% \\
0,0 \% \\
95,6 \% \\
96,6 \%\end{array}$ \\
\hline
\end{tabular}

(Sumber : Hasil olahan DEA)

Dari tabel di atas dapat dilihat bahwa ketidakefisienan Puskesmas dapat dinilai dari dua hal, yang pertama angka input pada kolom target terlihat lebih kecil dari angka input dalam kolom actual. Dapat diartikan pula bahwa pencapaian output belum pada titik optimal. Hal ini menyebabkan terdapat kelebihan alokasi baik dari segi infrastruktur, peralatan, alokasi biaya dan SDM tenaga kerja. Kondisi kedua terjadi apabila angka output pada kolom target lebih besar jika dibandingkan dengan angka output pada kolom actual, dapat diartikan pula bahwa pencapaian yang seharusnya dapat ditangani sesuai dengan target, namun belum dapat dikerjakan dengan optimal. Tertuju pada pencapaian yang belum $100 \%$ harus dijadikan sebagai tolak ukur perubahan terhadap input dan output yang harus segera diperbaiki. Dapat dilihat ketidakefisienan Puskesmas JIMFE (Jurnal Ilmiah Manajemen Fakultas Ekonomi) Volume 2 No. 2 Tahun 2016, Hal. 26-50 
Warung Jambu (Skor 91,16\%). Terdapat ketidakoptimalan penggunaan pada variabel input dan output sehingga pencapaian belum pada titik optimal (achieved 100\%). Untuk variabel input yaitu infrastruktur fisik pencapaian $100 \%$ (sudah optimal), indeks peralatan pencapaian $97 \%$ (tidak optimal), jumlah tempat tidur pencapaian $83,3 \%$ (tidak optimal), pengeluaran obat pencapaian $70,6 \%$ (tidak optimal), pengeluaran pemeliharaan pencapaian $90,7 \%$ (tidak optimal), infrastruktur khusus pencapaian 94,2\% (tidak optimal), peralatan khusus pencapaian $94,2 \%$ (tidak optimal), jam OPD per minggu pencapaian 95,3\% (tidak optimal), jam laboratorium per minggu pencapaian 97,6\% (tidak optimal), dokter pencapaian $100 \%$ (sudah optimal), perawat $89,4 \%$ (tidak optimal), paramedis 97,9\% (tidak optimal), tenaga administratif $97,9 \%$ (tidak optimal), tenaga non-tehnis $62,4 \%$ (tidak optimal). Sedangkan untuk variebel output yaitu beberapa penganan yang telah dilakukan oleh Puskesmas diantaranya, kasus laboraturium $89,8 \%$ (belum optimal), penanganan pasien rawat Jalan $96,1 \%$ (belum optimal), penanganan kasus kesehatan ibu dan anak $90,6 \%$ (belum optimal).

\section{Puskesmas Inefisien dan Perbaikannya}

Telah dijelaskan pada pembahasan sebelumnya bahwa Puskesmas dinyatakan inefisien jika variabel input dan output yang digunakan dalam analisis ini belum seluruhnya tercapai pencapaian yang optimal (achieved 100\%), oleh karena itu pengoptimalan variabel input dan output memiliki sentra yang sangat dominan ketika terdapat variabel yang tidak memiliki fungsi yang tepat dalam penunjang sistem kerja Puskesmas. Berikut hal-hal yang perlu dilakukan perbaikan terhadap Puskesmas yang belum efisien:

\section{Puskesmas Warung Jambu}

Untuk mengoptimalkan variabel input dan output dapat dilakukan dengan cara melihat target dari table of target values hasil perhitungan dari analisis DEA.

Tabel 3.7Table of Target Values Puskesmas Warung Jambu

\begin{tabular}{|c|c|c|c|c|c|c|}
\hline \multirow[b]{2}{*}{ Puskesmas } & \multirow[b]{2}{*}{ Score } & \multirow[b]{2}{*}{ Variabel } & \multicolumn{4}{|c|}{ Perbaikan Mengacu Benchmarks } \\
\hline & & & Actual & Target & $\begin{array}{c}\text { To Gain } \\
(\%)\end{array}$ & $\begin{array}{c}\text { Achived } \\
(\%)\end{array}$ \\
\hline \multirow[t]{15}{*}{$\begin{array}{l}\text { Warung } \\
\text { Jambu }\end{array}$} & \multirow[t]{15}{*}{$91,16 \%$} & Infrastruktur Fisik & 0,643434 & 0,643434 & $0 \%$ & $100,0 \%$ \\
\hline & & Indeks Peralatan & 0,963263 & 0,934768 & $3 \%$ & $97,0 \%$ \\
\hline & & Jumlah tempat tidur & 12 & 10 & $17 \%$ & $83,3 \%$ \\
\hline & & Pengeluaran obat (Rp) & 352.589 .632 & 248.778 .225 & $29 \%$ & $70,6 \%$ \\
\hline & & Pengeluaran pemeliharaan ( $\mathrm{Rp})$ & 197.502.716 & 179.172 .214 & $9 \%$ & $90,7 \%$ \\
\hline & & Infrastruktur Khusus & 6,3 & 5,9 & $6 \%$ & $93,7 \%$ \\
\hline & & Peralatan Khusus & 34,02 & 32,05 & $6 \%$ & $94,2 \%$ \\
\hline & & Jam OPD per minggu & 38,45 & 36,65 & $5 \%$ & $95,3 \%$ \\
\hline & & Jam laboraturium per minggu & 94,7 & 92,40 & $2 \%$ & $97,6 \%$ \\
\hline & & Dokter & 3 & 3 & $0 \%$ & $100,0 \%$ \\
\hline & & Perawat & 7 & 6,25462 & $11 \%$ & $89,4 \%$ \\
\hline & & Paramedis & 8 & 7,83246 & $2 \%$ & $97,9 \%$ \\
\hline & & Administratif & 4 & 3,74194 & $6 \%$ & $93,5 \%$ \\
\hline & & Non-Tehnis & 3 & 1,87097 & $38 \%$ & $62,4 \%$ \\
\hline & & Kasus Legal Medis & 0 & 0 & $0 \%$ & $0,0 \%$ \\
\hline
\end{tabular}

JIMFE (Jurnal Ilmiah Manajemen Fakultas Ekonomi)

Volume 2 No. 2 Tahun 2016, Hal. 26-50 


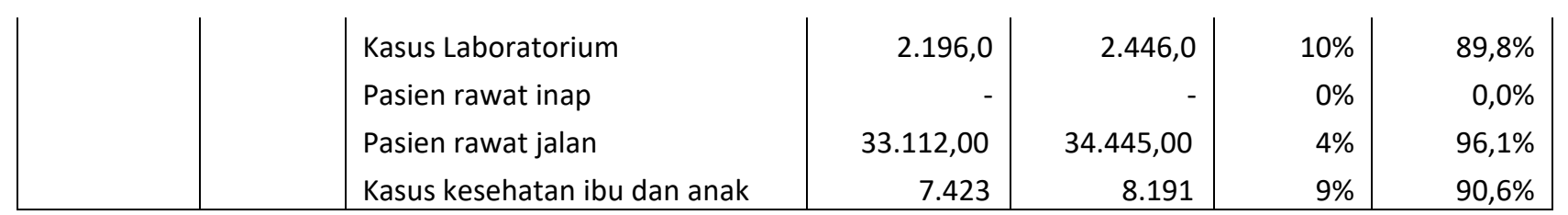

(Sumber : Hasil Olahan DEA)

Berdasarkan tabel di atas hampir semua variabel input tidak mencapai efisiensi optimal (Achieved 100\%). Untuk menjadi efisien, Puskesmas Warung Jambu harus mengurangi input yang besarnya dapat dilhat pada kolom "to gain". Sedangkan kolom "Target" menunjukkan besarnya penyesuaian dari setiap variabel yang dinyatakan dalam satuan masing-masing. Misalnya variabel input untuk biaya pengeluaran obat harus dikurangi sebesar ((Nilai Actual - To Gain (\%)). Jadi biaya pengeluaran obat harus dikurangi sebesar (Rp352.589.632-29\% = Rp248.778.225), dengan menurunkan biaya sebesar Rp103.811.407 maka pencapaian akan sesuai dengan target yang telah ditetapkan yaitu sebesar Rp248.778.225， (Rp352.589.632 Rp103.811.407 = Rp248.778.225). Hal ini dapat juga digunakan untuk variabel input yang lain untuk mengoptimalkan masingmasing nilai guna tercapainya tujuan yang telah ditetapkan. Berbeda dengan variabel output yang belum optimal, untuk memperoleh output yang optimal harus menambahkan to gain \% dengan nilai actual yang telah diraih. Misal untuk mengoptimalkan variabel output penanganan kasus kesehatan ibu dan anak, maka penanganan yang harus dilakukan agar tercapai output yang optimal adalah dengan cara meningkatkan penanganan kesehatan ibu dan anak sebesar $(9 \% \times 7.423=768)$, dengan demikian nilai target adalah 8.191 orang $(7.423+768)$. Untuk output lain yang belum optimal dapat disesuaikan dengan cara yang sama.

\section{Puskesmas Sempur}

Berdasarkan hasil perhitungan DEA, nilai efisiensi Puskesmas Sempur adalah sebesar 93,75\% sehingga dinyatakan tidak efisien secara teknis. Agar Puskesmas Sempur menjadi efisien dilakukan kebijakan penyesuaian nilai variabel input dan output agar dapat berjalan dengan optimal. Berikut poin perbaikan dapat dijelaskan dalam tabel 3.8.

Tabel 3.8.Table of Target Values Puskesmas Sempur

\begin{tabular}{|l|l|l|r|r|r|r|}
\hline \multirow{2}{*}{ Puskesmas } & \multirow{2}{*}{ Score } & \multicolumn{1}{c|}{ Variabel } & \multicolumn{2}{|c|}{ Perbaikan Mengacu Benchmarks } \\
\cline { 3 - 6 } & & & Actual & Target & $\begin{array}{c}\text { To Gain } \\
\text { (\%) }\end{array}$ & $\begin{array}{c}\text { Achived } \\
\text { (\%) }\end{array}$ \\
\hline Sempur & $93,75 \%$ & Infrastruktur Fisik & 0,852212 & 0,852212 & $0 \%$ & $100,0 \%$ \\
& & Indeks Peralatan & 0,986421 & 0,924723 & $6 \%$ & $93,7 \%$ \\
& & Jumlah tempat tidur & 10 & 10 & $0 \%$ & $100,0 \%$ \\
& & Pengeluaran obat (Rp) & 279.681 .782 & 279.681 .782 & $0 \%$ & $100,0 \%$ \\
& & Pengeluaran pemeliharaan (Rp) & 215.078 .910 & 197.468 .515 & $8 \%$ & $91,8 \%$ \\
& & 18 & 16,4 & $9 \%$ & $91,1 \%$ \\
& & Infrastruktur Khusus & 35,01 & 31,08 & $11 \%$ & $88,8 \%$ \\
& & Peralatan Khusus & 38,55 & 36,8 & $5 \%$ & $95,5 \%$ \\
& Jam OPD per minggu & 94,56 & 92,72 & $2 \%$ & $98,1 \%$ \\
& & Jam laboraturium per minggu & 2 & 2 & $0 \%$ & $100,0 \%$ \\
& Dokter & 7 & 5,63521 & $19 \%$ & $80,5 \%$
\end{tabular}




\begin{tabular}{|l|l|} 
Paramedis \\
Administratif \\
Non-Tehnis \\
Kasus Legal Medis \\
Kasus Laboratorium \\
Pasien rawat inap \\
Pasien rawat jalan \\
Kasus kesehatan ibu dan anak
\end{tabular}

(Sumber : Hasil Olahan DEA)

Sama halnya dengan cara pengoptimalan Puskesmas yang sebelumnya bahwa untuk mengoptimalkan variabel input pada Puskesmas Sempur dibutuhkan penyesuaian terhadap nilai actual yang telah dipergunakan untuk kedepannya agar tidak melebihi dengan nilai target yang telah ditetapkan, misalnya untuk variable input pengeluaran pemeliharaan yang belum optimal untuk Puskesmas Sempur dengan pencapaian $91,8 \%$. Dapat dilakukan pengoptimalan pengeluaran dengan mengurangi nilai actual yang telah terjadi. Jadi untuk pengeluaran pemeliharaan dikurangi sebesar (Rp215.078.910 - 8\% = Rp197.468.515), dengan menurunkan biaya sebesar Rp17.610.395 maka pencapaian akan sesuai dengan target yang telah ditetapkan yaitu sebesar Rp197.468.515 (Rp215.078.910 Rp17.610.395 = Rp.197.468.515). Untuk memperoleh output yang optimal harus menambahkan to gain\% dengan nilai actual yang telah diraih. Misal untuk mengoptimalkan variabel outputpenanganan pasien rawat jalan, maka penanganan yang harus dilakukan agar tercapai output yang optimal adalah dengan cara meningkatkan penanganan pasien rawat jalan sebesar $(4 \%$ X 33.126 = 1.537), dengan demikian nilai target adalah 34.663 orang $(33.126+1.537)$. Untuk output lain yang belum optimal dapat disesuaikan dengan cara yang sama.

\section{KESIMPULAN}

Dari hasil analisis yang telah dilakukan terhadap Puskesmas yang ada di kota bogor, enam Puskesmas yang diteliti diantaranya: Puskesmas Bogor Timur, Puskesmas Warung Jambu, Puskesmas Kayu Manis, Puskesmas Sempur, Puskesmas Bogor Selatan dan Puskesmas Tanah Sareal, dari ke enam Puskesmas tersebut terdapat beberapa penilaian baik dari segi persepsi masyarakat maupun tingkat keefisienan dari kinerja yang telah diberikan kepada masyarakat, berikut beberapa kesimpulan tersebut:

1. Faktor-faktor lingkungan yang paling penting yang menyebabkan ragam pada kinerja Puskesmas

- Tingkat kunjungan masyarakat terhadap Puskesmas dalam tiga bulan terakhir tergolong tinggi, rata-rata di atas $50 \%$ dari responden mengatakan bahwa masyarakat melakukan kunjungan dalam tiga bulan terakhir, ini menandakan jasa pelayanan Puskesmas masih diminati oleh masyarakat.

- Untuk intensitas kunjungan masyarakat setiap bulannya rata-rata setiap responden melakukan kunjungan sebanyak dua sampai tiga kali dalam sebulan. Masyarakat masih sangat bergantung terhadap jasa pelayanan Puskesmas.

- Penilaian masyarakat terhadap tingkat kepentingan jasa pelayanan yang diberikan oleh Puskesmas: Penanganan pasien: dinilai Sangat penting (rata-rata responden di setiap Puskesmas menilai penanganan terhadap pasien sangat 
penting). Kebersihan fasilitas: Dinilai sangat penting dari rata-rata responden di setiap Puskesmas. Harga: Dinilai sangat penting oleh masyarakat, keterjangkauan harga sangat memudahkan masyarakat untuk dapat menikmati jasa layanan Puskesmas. Ragam pengobatan: Dinilai sangat penting dalam memberikan jenis ragam pengobatan terhadap masyarakat.

- Penilaian masyarakat tentang kepuasan jasa pelayanan yang diberikan oleh Puskesmas: penanganan pasien: Lima dari enam Puskesmas, masyarakat memberikan penilaian penaganan pasien baik terhadap pelayanan yang diberikan. Hanya Puskesmas Warung jambu 59\% responden mengatakan bahwa penaganan pasien buruk. Kebersihan: Tiga Ppuskesmas (Sempur, Bogor selatan dan Tanah Sareal) dominan responden memberikan penilaian bahwa fasilitas puskesmas tergolong bersih. Sedangkan tiga Puskesmas lainnya (Bogor Timur, Warung Jambu, Kayu Manis) rata-rata dominan responden menyebutkan bahwa fasilitas Puskesmas tidak bersih. Harga: Seluruh Puskesmas rata-rata $60 \%$ lebih responden mengatakan bahwa harga dari jasa pelayanan kesehatan di Puskesmas tergolong murah. Ragam pengobatan: Empat dari enam Puskesmas memperoleh penilaian jasa pengobatan yang diberikan sangat luas atau beragam (Warung Jambu, Sempur, Bogor Selatan dan Tanah Sareal). Sedangkan dua Puskesmas mendapat penilaian bahwa pengobatan yang ditawarkan sempit atau pengobatan terbatas.

- Harapan masyarakat terhadap pelayanan yang diberikan oleh Puskesmas: Pelayanan yang ramah: rata-rata responden dari seluruh Puskesmas meyatakan sangat setuju akan pelayanan yang diberikan dengan keramahan. Ketepatan diagnosa: Dinilai sangat setuju dari setiap responden akan ketepatan diagnosa yang diberikan oleh tenaga medis Puskesmas. Ketelitian pemeriksaan: Lebih dari $57 \%$ responden menyatakan bahwa konteks ini sangat setuju dan lebih dari $18 \%$ mengatakan setuju akan ketelitian pemeriksaan terhadap pasien. Keterampilan mengobati (kecepatan bertindak): Dinilai sangat setuju lebih dari $60 \%$ mengatakan demikian, lebih dari $20 \%$ menyatakan setuju.

- Penilaian tingkat kepentingan media informasi sebagai sarana pemberi informasi kepada masyarakat. Televisi : Dari keseluruhan responden lebih dominan menyatakan bahwa media promosi melalui televisi dinilai penting bahkan juga sangat penting. Tidak lebih dari $35 \%$ di tiga Puskesmas yang menyatakan bahwa sumber informasi dari televisi dinilai bukan sumber penting. Koran: Media informasi koran dinilai sumber yang penting untuk menginformasikan keberadaan akan Puskesmas di tengah-tengah masyarakat. Papan reklame: Dinilai sumber informasi yang penting bahkan sangat penting bagi masyarakat. Surat: Merupakan sumber penting bagi sebagian besar masyarakat, namun ada beberapa pendapat dari masyarakat yang menyatakan surat bukan merupakan sumber penting untuk memperoleh informasi tentang keberadaan Puskesmas.

- Penilaian masyarakat terhadap pelayanan yang telah dilakukan oleh masing-masing Puskesmas. Pelayanan ramah: Lima dari enam 
Puskesmas mendapatkan penilaian yang baik berkaitan dengan pelayanan yang diberikan oleh Puskesmas (Bogor Timur, Kayu Manis, Sempur, Bogor Selatan, Tanah Sareal). Untuk Puskesmas Warung Jambu lebih dominan 59\% masyarakat menyatakan bahwa pelayanan Puskesmas tergolong buruk dalam pelayanan yang ramah. Ketepatan diagnosa: Lima Puskesmas memiliki penilaian Baik (Bogor Timur, Kayu Manis, Sempur, Bogor Selatan, dan Tanah Sareal). Untuk Puskesmas Warung Jambu masyarakat memberikan penilaian yang buruk akan ketepatan diagnosa yang diberikan oleh pihak Puskesmas. Ketelitian pemeriksaan: Puskesmas dengan penilaian baik (Bogor Timur $60 \%$, Kayu Manis $74 \%$, Sempur $83 \%$, Bogor Selatan $80 \%$, Tanah Sareal $67 \%)$. Puskesmas dengan penilaian buruk (Warung Jambu 59\% responden menyatakan ketelitian pemeriksaan masih tergolong buruk). Keterampilan mengobati (kecepatan bertindak): Penilaian dari setiap pelayanan Puskesmas akan keterampilan mengobati dan kecepatan dalam bertindak rata-rata lebih dominan masyarakat memberikan penilaian baik. Pemberian layanan rujukan yang cepat dan tepat: Persepsi masyarakat memberikan penilaian yang baik pada setiap Puskesmas atas layanan ini.

- Tingkat kunjungan terhadap beberapa pelayanan medis dalam tiga bulan terakhir: Puskesmas: Ratarata lebih dari $55 \%$ masyarakat melakukan kunjungan terhadap Puskesmas satu kali dalam sebulan, 9\% melakukan kunjungan dua sampai tiga kali dalam sebulan, $30 \%$ melakukan kunjungan satu kali seminggu. Dokter praktek: $66 \%$ masyarakat melakukan kunjungan terhadap dokter praktek satu kali dalam sebulan, $7 \%$ melakukan kunjungan dua sampai tiga kali dalam sebulan, $10 \%$ melakukan kunjungan satu kali seminggu. Rumah sakit: $74 \%$ masyarakat melakukan kunjungan terhadap rumah sakit satu kali dalam sebulan, $5 \%$ melakukan kunjungan dua sampai tiga kali dalam sebulan, 4\% melakukan kunjungan satu kali seminggu. Lainnya: 45\% masyarakat melakukan kunjungan terhadap jasa kesehatan lainnya satu kali dalam sebulan, $11 \%$ melakukan kunjungan dua sampai tiga kali dalam sebulan, 4\% melakukan kunjungan satu kali seminggu.

- Karakteristi responden: jenis kelamin responden: Untuk Puskesmas Bogor Timur 20\% responden laki-laki, $80 \%$ perempuan, Puskesmas Warung Jambu 59\% laki-laki, 41\% perempuan, Puskesmas Kayu Manis 5\% laki-laki, 74\% perempuan, Puskesmas Sempur $52 \%$ laki-laki, $48 \%$ perempuan, Puskesmas Bogor Selatan 40\% lakilaki, $60 \%$ perempuan, Puskesmas Tanah Sareal $40 \%$ laki-laki, $60 \%$ perempuan. Status hubungan responden: Rata-rata dominan pengunjung setiap Puskesmas berstatus menikah. Anggota keluarga dengan umur dibawah 18 tahun: Untuk Puskesmas Bogor Timur 40\% responden memiliki 4 orang keluarga di bawah 18 tahun, Puskesmas Warung Jambu $41 \%$ tidak memiliki keluarga dengan umur dibawah 18 tahun. Untuk Puskesmas Kayu Manis, Sempur, Bogor Selatan dan Tanah Sareal dengan rata-rata dominan lebih dari $40 \%$ memiliki anggota keluarga berumur dibawah 18 tahun sebanyak dua orang. Rata-rata umur responden: Untuk rata-rata umur responden di setiap Puskesmas paling 
dominan berusia 25-39 tahun. Tingkat pendapatan responden: Pendapatan pertahun untuk responden paling dominan dengan pendapatan kurang dari 10 juta.

2. Hasil pengukuran efisiensi relatif Puskesmas umum di sektor publik menggunakan DEA model BCC (asumsi VRS) orientasi input dan output diperoleh dari enam Puskesmas di Kota Bogor terdapat 4 Puskesmas yang masuk dalam kategori Puskesmas efisien (Achieved 100\%), diantaranya Puskesmas Bogor Timur, Puskesmas Kayu Manis, Puskesmas Bogor Selatan dan Puskesmas Tanah Sareal. Untuk Puskesmas yang tergolong dalam Puskesmas inefisien diantaranya adalah Puskesmas Warung Jambu (Achieved 91,16\%) dan Puskesmas Sempur (Achieved 93,75\%).

3. Dari hasil perhitungan analisis DEA terdapat beberapa faktor-faktor yang menjadikan Puskesmas Warung Jambu dan Puskesmas Sempur menjadi tidak efisien, diantaranya: Nilai variabel input pada actual input lebih besar dibandingkan dengan target input yang telah ditetapkan. Nilai variable output pada actual output lebih kecil pencapaiannya dibandingkan dengan target output yang telah ditetapkan.

\section{SARAN}

Berikut adalah beberapa saran yang dapat dihasilkan dari penelitian ini:

1. Penilaian masyarakat terhadap tingkat kepentingan jasa pelayanan yang diberikan oleh Puskesmas: Penanganan Pasien: Karena dinilai Sangat penting maka perlunya ketanggapan dan ketepatan pelayanan bagi pasien agar respon yang cepat dan tepat dapat membantu pasien akan memenuhi maksud dan tujuan pasien dalam melakukan pengobatan. Kebersihan Fasilitas: Demi kenyamanan dalam berobat perlu diperhatikan tingkat kebersihan dari semua sarana dari lingkungan Puskesmas. Harga: Keterjangkauan harga diperlukan demi mendapatkan pemerataan bagi masyarakat untuk memperoleh fasilitas pengobatan. Dengan harga yang terjangkau dan pelayanan yang prima diharapkan Puskesmas menjadi penopang kesehatan yang di utamakan oleh masyarakat. Ragam pengobatan: Lebih diberagamkan lagi pelayanan kesehatan yang diberikan agar semua lapisan masyarakat dapat menikmati jasa layanan kesehatan ini dengan mudah dan terjangkau. Penilaian masyarakat tentang kepuasan jasa pelayanan yang diberikan oleh Puskesmas: Penanganan pasien: Setidaknya terdapat dua Puskesmas dominan mendapat penilaian buruk terhadap penanganan pasien, yaitu Puskesmas Bogor Timur dan Puskesmas Warung Jambu, agar kiranya memperbaiki pelayanan tersebut, memberikan penanganan yang cepat, tepat dan akurat terhadap pasien. Kebersihan: tiga Puskesmas (Sempur, Bogor selatan dan Tanah Sareal) agar tetap menjaga dan meningkatkan kebersihan lingkungan Puskesmas. Sedangkan tiga Puskesmas lainnya (Bogor Timur, Warung Jambu, Kayu Manis) harus memperbaiki tingkat kebersihan lingkungan Puskesmas. Harga: Dominan responden menyatakan bahwa harga/biaya yang dikeluarkan untuk berobat di Puskesmas tergolong murah, agar kiranya keterjangkauan harga ini juga dibarengi dengan pelayanan yang memuaskan bagi pasien. Ragam pengobatan: Dua Puskesmas mendapat penilaian pengobatan yang dilakukan sempit/terbatas, maka setidaknya memberikan pelayanan dengan standar yang sama dalam pengobatan yang diberikan, yaitu dengan melengkapi peralatan penunjang 
kesehatan yang lebih lengkap dan menambah tenaga ahli kesehatan untuk dapat melayani masyarakat dengan kebutuhan akan kesehatan yang lebih komplek.

Harapan masyarakat terhadap pelayanan yang diberikan oleh Puskesmas: Pelayanan yang ramah: Agar tetap dipertahankan dengan pelayanan yang telah diberikan kepada masyarakat. Ketepatan diagnosa: Ketelitian dan keakuratan pelayanan kesehatan tetap menjadi harapan bagi kepentingan pengobatan masyarakat. Ketelitian pemeriksaan: Tetap dipertahankan agar kepercayaan masyarakat terhadap pelayanan Puskesmas menjadi yang paling utama. Keterampilan mengobati (Kecepatan bertindak): Tidak hanya kecepatan bertindak saja yang dibutuhkan oleh pasien namun keterampilan melakukan pengobatan menjadi faktor yang sangat penting.

Media informasi sebagai sarana pemberi informasi kepada masyarakat. Televisi: Memberikan informasi tentang keberadaan Puskesmas terdekat di tengah-tengah masyarakat, pemerintah daerah harus bekerja sama dengan stasiun TV baik swasta ataupun nasional untuk bekerjasama mempromosikan Puskesmas terhadap masyarakat luas. Koran: Menginformasikan pada media cetak mengenai jasa pelayanan Puskesmas demi luasnya capaian informasi yang dapat diketahui oleh semua kalangan. Papan reklame: Memasang reklame pada tempat-tempat strategis untuk terjangkaunya informasi yang disampaikan. Surat: Lebih ditingkatkan lagi dalam pemberian informasi dari alat promosi ini, memudahkan masyarakat untuk mengetahui lebih detail programprogram kesehatan apa saja yang diberikan kepada masyarakat.

Penilaian masyarakat terhadap pelayanan yang telah dilakukan oleh masing-masing Puskesmas. Pelayanan ramah: Untuk Puskesmas dengan penilian yang positif agar tetap meningkatkan pelayanan yang ramah terhadap masyarakat, sedangkan untuk Puskesmas Warung Jambu agar segera memperbaiki pelayanan akan keramahan terhadap masyarakat. Ketepatan diagnosa: Puskesmas yang belum optimal dalam menetapkan diagnosa kepada pasien agar segera diperbaiki untuk lebih teliti dan akurat terhadap pemeriksaan pasien. Ketelitian Pemeriksaan: Untuk menjadi perhatian semua Puskesmas khususnya juga Puskesmas Warung Jambu akan melakukan perbaikan terhadap tingkat ketelitian pemeriksaan demi tercapainya keakuratan pengobatan. Keterampilan mengobati (kecepatan bertindak): Setiap Puskesmas harus dapat mempertahankan dan meningkatkan kembali pelayanan ini. Pemberian layanan rujukan yang cepat dan tepat: Relatif terhadap semua Puskesmas telah melakukan layanan ini dengan baik, lebih tanggap lagi dan memberikan pelayanan yang prima akan kebutuhan masyarakat.

2. Untuk mengoptimalkan kembali fungsi Puskesmas yang tidak efisien maka dapat menggunakan pendekatan input dan output pada masing-masing variabel dengan menyesuaikan nilai input dan output yang besarnya mengacu pada benchmark Puskesmas efisien. Untuk mencapai nilai tersebut, beberapa saran kebijakan yang harus dilakukan yaitu:

3. 
Tabel 4.1. Rekomendasi untuk mengoptimalkan Input dan Output Puskesmas Inefisien

\begin{tabular}{|c|c|c|c|c|c|c|c|c|c|}
\hline \multirow[b]{2}{*}{ No } & \multirow[b]{2}{*}{ Puskesmas } & \multirow[b]{2}{*}{ Score } & \multirow[b]{2}{*}{ Variabel } & \multicolumn{3}{|c|}{ Perbaikan Mengacu Benchmarks } & \multicolumn{2}{|c|}{ Adjusment } & \multirow[b]{2}{*}{$\begin{array}{c}\text { Achived } \\
\text { (\%) }\end{array}$} \\
\hline & & & & Actual & Target & $\begin{array}{c}\text { To Gain } \\
\text { (\%) }\end{array}$ & $\begin{array}{c}\text { Mengurangi } \\
\text { Input }\end{array}$ & $\begin{array}{c}\text { Menambah } \\
\text { Output }\end{array}$ & \\
\hline 1 & Warung Jambu & $91,16 \%$ & $\begin{array}{l}\text { Infrastruktur Fisik } \\
\text { Indeks Peralatan } \\
\text { Jumlah tempat tidur } \\
\text { Pengeluaran obat }(\mathrm{Rp}) \\
\text { Pengeluaran pemeliharaan (Rp) } \\
\text { Infrastruktur Khusus } \\
\text { Peralatan Khusus } \\
\text { Jam OPD per minggu } \\
\text { Jam laboraturium per minggu } \\
\text { Dokter } \\
\text { Perawat } \\
\text { Paramedis } \\
\text { Administratif } \\
\text { Non Tehnis } \\
\text { Kasus Legal Medis } \\
\text { Kasus Laboratorium } \\
\text { Pasien rawat inap } \\
\text { Pasien rawat jalan } \\
\text { Kasus kesehatan ibu dan anak } \\
\end{array}$ & $\begin{array}{c}0,643434 \\
0,963263 \\
12 \\
352.589 .632 \\
197.502 .716 \\
6,3 \\
34,02 \\
38,45 \\
94,7 \\
3 \\
7 \\
8 \\
4 \\
3 \\
0 \\
15.352,4 \\
5.953,7 \\
44.291,47 \\
10.962 \\
\end{array}$ & $\begin{array}{c}0,643434 \\
0,934768 \\
10 \\
248.778 .225 \\
179.172 .214 \\
5,9 \\
32,05 \\
36,65 \\
92,40 \\
3 \\
6,25462 \\
7,83246 \\
3,74194 \\
1,87097 \\
0 \\
18.264,4 \\
6.566,05 \\
45.129,05 \\
11.321 \\
\end{array}$ & \begin{tabular}{|c|}
$0 \%$ \\
$3 \%$ \\
$17 \%$ \\
$29 \%$ \\
$9 \%$ \\
$6 \%$ \\
$6 \%$ \\
$5 \%$ \\
$2 \%$ \\
$0 \%$ \\
$11 \%$ \\
$2 \%$ \\
$6 \%$ \\
$38 \%$ \\
$16 \%$ \\
$16 \%$ \\
$9 \%$ \\
$2 \%$ \\
$3 \%$ \\
\end{tabular} & $\begin{array}{c}0 \\
0,028495 \\
2 \\
103.811 .407 \\
18.330 .502 \\
0,4 \\
1,97 \\
1,8 \\
2,3 \\
0 \\
0,75 \\
0,17 \\
0,26 \\
1,13\end{array}$ & $\begin{array}{c}0 \\
2912 \\
612 \\
838 \\
359 \\
\end{array}$ & $\begin{array}{l}100 \% \\
100 \% \\
100 \% \\
100 \% \\
100 \% \\
100 \% \\
100 \% \\
100 \% \\
100 \% \\
100 \% \\
100 \% \\
100 \% \\
100 \% \\
100 \% \\
100 \% \\
100 \% \\
100 \% \\
100 \% \\
100 \% \\
\end{array}$ \\
\hline 2 & Sempur & $93,75 \%$ & $\begin{array}{l}\text { Infrastruktur Fisik } \\
\text { Indeks Peralatan } \\
\text { Jumlah tempat tidur } \\
\text { Pengeluaran obat (Rp) } \\
\text { Pengeluaran pemeliharaan (Rp) } \\
\text { Infrastruktur Khusus } \\
\text { Peralatan Khusus } \\
\text { Jam OPD per minggu } \\
\text { Jam laboraturium per minggu } \\
\text { Dokter } \\
\text { Perawat } \\
\text { Paramedis } \\
\text { Administratif } \\
\text { Non Tehnis } \\
\text { Kasus Legal Medis } \\
\text { Kasus Laboratorium } \\
\text { Pasien rawat inap } \\
\text { Pasien rawat jalan } \\
\text { Kasus kesehatan ibu dan anak }\end{array}$ & $\begin{array}{c}0,852212 \\
0,986421 \\
10 \\
279.681 .782 \\
215.078 .910 \\
18 \\
35,01 \\
38,55 \\
94,56 \\
2 \\
7 \\
8 \\
4 \\
2 \\
0 \\
18.971,4 \\
5.953,7 \\
45.857,23 \\
9.578\end{array}$ & $\begin{array}{c}0,852212 \\
0,924723 \\
10 \\
279.681 .782 \\
197.468 .515 \\
16,4 \\
31,08 \\
36,8 \\
92,72 \\
2 \\
5,63521 \\
8 \\
4 \\
1,26594 \\
0 \\
19.472,7 \\
6.566,05 \\
47.136,05 \\
10.843\end{array}$ & $\begin{array}{c}0 \% \\
6 \% \\
0 \% \\
0 \% \\
8 \% \\
9 \% \\
11 \% \\
5 \% \\
2 \% \\
0 \% \\
19 \% \\
0 \% \\
0 \% \\
37 \% \\
0 \% \\
3 \% \\
9 \% \\
3 \% \\
12 \% \\
\end{array}$ & $\begin{array}{c}0 \\
0,061698 \\
0 \\
0 \\
17.610 .395 \\
1,6 \\
3,9 \\
1,75 \\
1,84 \\
0 \\
1,36479 \\
0 \\
0 \\
0,73406\end{array}$ & $\begin{array}{r}- \\
501,30 \\
612,31 \\
1.278,82 \\
1.265\end{array}$ & $\begin{array}{l}100 \% \\
100 \% \\
100 \% \\
100 \% \\
100 \% \\
100 \% \\
100 \% \\
100 \% \\
100 \% \\
100 \% \\
100 \% \\
100 \% \\
100 \% \\
100 \% \\
100 \% \\
100 \% \\
100 \% \\
100 \% \\
100 \%\end{array}$ \\
\hline
\end{tabular}

4. Tingkat efisiensi dari Puskesmas Warung Jambu dan Puskesmas Sempur dapat di optimalkan kembali dengan cara sebagai berikut: Optimalisasi variabel input: Dengan cara mengurangi nilai input sesuai dengan kelebihan nilai input yang digunakan (besarnya pengurangan dapat dilihat pada kolom "to gain") atau dalam artian nilai actual dikurangi dengan persentase kelebihan nilai input. Optimalisasi variabel output: Dengan cara menambahkan nilai output actual dengan persentase "to gain" atau dalam artian nilai output actual ditambah dengan persentase kekurangan nilai output.

\section{DAFTAR PUSTAKA}

Afonso, A., Fernandes, S. (2008), "Assessing and Explaining the Relative Efficiency of Local Government", The Journal of Socio-Economics, 37, pp. 1946-1979.

Al-Shammari, M. (1999), "A Multi-Criteria Data Envelopment Analysis Model for Measuring the Productive Efficiency of Hospitals", International Journal of Operations \& Production Management,19(9), pp. 879-890.

Aletras, V., Kontodimopoulos, N., Zagouldoudis, A., Niakas, D. (2007), "The Short-Term Effect on Technical and Scale Efficiency of Establishing Regional Health Systems and General Management in Greek NHS 
Hospitals", Health Policy, 83(2-3), pp. 236-245.

Ancarani, A., Dimauro, C., Giammanco, M.D. (2009), "The Impact of Managerial and Organizational Aspects on Hospital Wards' Efficiency: Evidence from a Case Study", European Journal of OperationalResearch, 194, pp. 280-293.

Astami, E. W., Tower, G., Rusmin, R., Neilson, J. (2010), "The Effect of Privatization on Performance of State-OwnedEnterprises in Indonesia", Asian Review of Accounting, 18(1), pp. 5-19.

Bachiller, P. (2009) "Effect of Ownership on Efficiency in Spanish Companies", Management Decision, 47(2), pp. 289307.

Balaguer-Coll, M.T., Prior, D., Tortosa-Ausina, E. (2007), "On the Determinants of Local Government Performance: A two-Stage nonparametric approach", European Economic Review, 51, pp. 425-451.

Bates, L J., College, B., Mukherjee, K., Santerre, R E. (2006), "Market Structure and Technical Efficiency in the Hospital Services Industry: A DEA Approach", Medical Care Research and Review, 63(4), pp. 499-524.

Charnes, A., Cooper, W.W., Rhodes, E.L. (1978), "Measuring the Efficiency of Decision Making Units", European Journal of Operational Research, 2, pp. 429-444.

Chen, A., Hwang, Y., Shao, B., (2005), "Measurement and Sources of Overall and Input Inefficiencies: Evidences and Implications in Hospital Services". European Journal of Operational Research, 161, pp. 447-468.

Cook, W.D., Seiford, L.M. (2009), "Data Envelopment Analysis (DEA) - Thirty Years on", European Journal of Operational Research, 192, pp. 1-17.

Daft, R.L. (2009), Organization Theory and Design, Cengage Learning, USA.

Farrell, M.J. (1957), "The Measurement of Productive Efficiency", Journal of the Royal Statistical Society, Series A, General 120 (3), pp. 253-281.
Fryer, K., Antony, J., Ogden, S. (2009) "Performance Management in the Public Sector", International Journal of Public Sector Management, 22(6), pp. 478-498.

Giokas, D. I. (2008), "Cost Efficiency Impact of Bank Branch Characteristics and Location an Illustrative Application to Greek Bank Branches", Managerial Finance, 34(3), pp. 172-185.

Groff , J. E., Lien, D., Su, J. (2007), “Measuring Efficiency Gains from Hospital Mergers", Research in Healthcare Financial Management, 11(1), pp. 77.

Grosskopf, H., Margaritis, D., Valdmanis, V. (2005), "The Effects of Teaching on Hospital Productivity", Socio-Economic Planning Sciences, 35, pp. 189-204.

Jacobs, R. (2001), "Alternative Methods to Examine Hospital Efficiency: Data Envelopment Analysis and Stochastic Frontier Analysis", Health Care Management Science, 4, pp. 103-115.

Jacobs, R., Smith, P.C., Street, A., (2006), Measuring Efficiency in Health Care, Cambridge: Cambridge University Press.

Kapyla, J., Jaaskelainen, A., Lonnqvist, A., (2010), "Identifying Future Challenges for Productivity Research: Evidence from Finland", International Journal of Productivity and Performance Management, 59(7), pp. 607-623.

Karlaftis, M.G. (2004), "A DEA Approach for Evaluating the Efficiency and Effectiveness of Urban Transit Systems", European Journal of Operational Research, 152, pp. 354-364.

Kazley, A.S., Ozcan, Y.A. (2009), "Electronic Medical Record Use and Efficiency: A DEA and Windows Analysis of Hospitals", Socio-Economic Planning Sciences, 43, pp. 209-216.

Langabeer, J.R. (2007), Health Care Operations Management: a Quantitative Approach to Business and Logistics, Jones \& Bartlett Learning.

Lee G., Lin, H., Pai, J. (2005), " Influence of Environmental and Organizational Factors on the Success of Internet-Based Interorganizational Systems Planning", Internet Research, 15(5), pp. 527-543. 
Lee, R.P., Ginn, G.O., Naylor, G. (2009), "The Impact of Network and Environmental Factors on Service Innovativeness", Journal of Services Marketing, 23(6), pp. 397-406.

Mason, R.B. (2007), "The external environment's effect on management and strategy A complexity theory approach", Management Decision, 45(1), pp. 10-28.

O'Neill, L., Rauner, M., Heidenberger, K., Kraus, M. (2008), "A Cross-national Comparison and Taxonomy of DEA-based Hospital Efficiency Studies", Socio-Economic Planning Sciences, Vol. 42, pp. 158-189.

Ozcan, Y.A., (2007), Health Care Benchmarking and Performance Evaluation: an Assessment Using Data Envelopment Analysis (DEA), Springer Science and Business Media.

Prado-Lorenzo, J. M., Garcia-Sanche, I. M. (2010), "Effect of Operation Size, Environmental Conditions and Management on Municipal Sewerage Services", International Journal of Productivity and Performance Management, 59(3), pp. 206-228.

Puig-Junoy, J. (2000), "Partitioning Input Cost Efficiency Into Its Allocative and Technical Components: An Empirical DEA Application to Hospitals", Socio-
Economic Planning Sciences, 34, pp. 199-218.

Sadjadi, S.J., Omrani, H. (2008), "Data Envelopment Analysis with Uncertain Data: An Application for Iranian Electricity Distribution Companies", Energy Policy, 36, pp. 4247-4254.

Sherman, H.D. (1984), "Hospital efficiency measurement and evaluation", Medical Care, 22(10), pp. 922 -939.

Simar, L. and Wilson, P.W. (2007), "Estimation and Inference in Two-stage, SemiParametric Models of Production Processes", Journal of Econometrics, 136, pp. 31-64.

Taticchi, P., Tonelli, F., Cagnazzo, L. (2010), "Performance Measurement and Management: a Literature Review and a Research Agenda", Measuring Business Excellence, 14(1), pp. 4-18.

Tiemann, O., Schreyögg, J., "Effects of Ownership on Hospital Efficiency in Germany - A Tobit Panel Data Approach Based on DEA Efficiency Scores", 7th Conference on Applied Infrastructure Research, Berlin, October 2008.

Zhu, J. (2009), Quantitative Models for Performance Evaluation and Benchmarking: Data Envelopment Analysis with Spreadsheets and DEA Excel Solver, ISOR 54, Springer, USA. 